\title{
EFFECT OF SALES GROWTH AND CASH FLOWS ON GROWTH INCOME OF CERAMIC COMPANIESIN INDONESIA STOCK EXCHANGE
}

\author{
Novi Fadhila ${ }^{1}$, Sugrina ${ }^{2}$ \\ Economic and Business Faculty, University of Muhammadiyah Sumatera Utara \\ nfadhila2010@gmail.com ${ }^{1}$
}

\begin{abstract}
The purpose of this research is to know the influence of Sales Growth and Operating Cash Flow on Profit Growth at Ceramic Company in Indonesia Stock Exchange. This study uses an associative approach, using secondary data. The population in this study is a ceramic company listed on the Indonesian stock exchange. Sampling method in this research using saturated sampling technique amounted to 5 companies with 7 years of data. Data accessed via www. idx.co.id. The result of the research shows that simultaneously the growth of sales and the flow of operation has no significant effect to the profit growth in the ceramics company listed in Indonesia Stock Exchange. However, partially independent variables, is sales growth and cash flows of operating operations significantly to profit growth in ceramics companies listed on the Indonesia Stock Exchange.
\end{abstract}

\section{Keywords: Profit growth, Operating cash flow}

\section{INTRODUCTION}

A company aims to maximize the value of the company and maximize profits so that the company can survive in its activities and expand to expand its market share. Without the company's profitability cannot continue to grow, which is an absolute goal for every company with no differentiate the type of business. It is a demand for the company to be able to perform its operations effectively and efficiently, so that the management of its assets more effectively and efficiently. Uncertain profit growth, requires analysis to predict earnings growth. The analysis used is the analysis of financial statements with financial ratios to measure financial performance. The company's performance assessment reflects the financial condition to predict the company's profit growth. Good profit growth suggests a healthy company financial condition, thereby increasing the value of the company. Profit growth can be measured in terms of changes in retained earnings, as well as by looking at the alignment of investment and financing decisions. A sustained profit growth is seen in the company's growth with asset support for an increase in retained earnings. Sales growth is an increase in sales during the period where the sale is a company's operational activities that aim to profit or welfare employees and shareholders. Sales growth will move straight in line with the level of corporate profits. The cash flow statement can provide information that enables users to evaluate changes in the company's net assets, financial structure (including liquidity and solvency) and the ability to influence the amount and timing of cash flows in order to adapt to changing circumstances and opportunities.

The cash flow statement contains information with the inclusion of a cash flow statement in the financial statements, since the company's financial statements serve as a provider of information so investors react to stock investments (sale or purchase of shares) in the company. Growth in sales in 2010-2016 there is a decrease in some ceramic companies listed on the Stock Exchange this will result in the company's profits will decrease, while according to Kashmir (2012: 305) High sales growth will reflect increased revenue that will increase corporate profits. While data related to operating cash flow for the period 2010-2016 has decreased in some companies listed on Indonesia Stock Exchange, which shows the lack of ability of company in doing new investment to carry out operational activities of company. According to PSAK No. 2 (IAI, 2007: 3) "Cash flows from operating activities are an indicator that determines whether a company's operations can generate sufficient cash flows to repay loans, maintain operating capability, pay dividends, and make new investments without relying external funding sources ". Operating activity is the main revenue generating activity of the company (principal 
revenue activities). The profit growth of 2010-2016 has decreased, which will affect more companies using external capital than their own capital, while according to Brealey Myers (2008: 120) Profit growth reflects a company with volume of profit that can produce higher growth rates without must accumulate more external capital if the increase in sales growth and internal growth of the company, consistent cash flow, the company has a good financial ratios.

\section{Profit Growth \\ Definition of Profit Growth}

Profit Growth is a change in the financial statements per year. Growth is related to how stability increases profit. An above-average profit growth for an enterprise is generally based on the expected rapid growth and the industry in which it operates. Growth The profit of a product depends on the product life cycle (Fabozzi 2000: 881).

According to Ratnawati (2007), sustained Profit Growth is the rate at which a company can grow depending on how asset support for an increase in retained earnings. In addition through the rate of profit growth can also be measured from the growth of assets or with investment opportunities are proxied with a variety of investment value set investment opportunity (Investment Opportunity Set).

Murni and Andriana (2007) states, the Growth Profit approach is a component to assess the prospects of the company in the future. It can be concluded that Profit Growth is a component to assess the prospects of the company in the future and in financial management is measured by comparison between the profit of the current period with the profit of the previous period.

\section{Benefit of Profit Growth}

According to Armstrong (2002: 327) as for the benefit of profit growth is as follows:

1) To measure a company's ability to pay its liabilities or debts immediately due when billed. That is, the ability to pay obligations that it was time to be paid according to the schedule stipulated deadline (date and a specific month).

2) To measure a company's ability to pay short-term liabilities with current assets as a whole.

3) To measure a company's ability to pay its short-term liabilities without taking into account inventories or receivables,

4) To measure or compare the amount of existing inventory with the company's working capital.

5) To measure how much cash is available to pay the debt.

\section{Factors affecting profit growth}

According to Angkoso (2006) states that profit growth is influenced by several factors, among others:

a. The size of the company.

The bigger a company, then the accuracy of expected higher profit growth.

b. Age of the company.

The newly established company lacks experience in improving profits, so its accuracy is still low.

c. Leverage level.

If the company has a high debt level, the managers tend to manipulate earnings so it can reduce the accuracy of earnings growth.

d. Sales level.

The high sales rate in the past, the higher the sales rate in the future so that the higher profit growth.

e. Past earnings changes.

The greater the change in past earnings, the more uncertain the profit earned in the future.

Profit growth can be calculated by the formula:

$$
\Delta \mathrm{Y}_{i t}=\frac{Y_{i t}-Y_{i t-n}}{Y_{i t-n}}
$$


Information :

$\Delta$ Yit $=$ Profit Growth

Yit $=$ Profit Period Now

Yit-n = Previous Earnings (Brealey, 2008: 120)

1.2 Sales Growth

1.2.1 Definition of Sales Growth

"Sales growth as one of the growth ratios is a ratio that indicates an increase in sales that can be achieved by a business entity." (Akbar, 2009: 25) With high sales growth, the company shows the ability to penetrate new markets or diversify products and distribution channels as well set the selling price. By knowing how big sales growth, the company can predict how much profit to be gained.

"The level of sales growth is the increase or decrease in the number of sales from year to year or from time to time." (Kesuma, 2009: 41) If a company that has a high rate of sales growth will require more investment in various asset elements, as well as current assets. The management should consider the appropriate source of funding for the asset's expenditure. Companies with high sales growth will be able to fulfill their financial obligations if the company buys its assets with debt.

\section{Factors affecting Sales Growth activities}

factors that need to be considered in increasing the sales growth are:

1. Selling price policy

2. Product Policy

3. Distribution Policy (J.P Sitanggang 2012: 65).

Sales growth is also influenced by several environmental factors namely:

1. Uncontrolled environmental factors, consisting of:

a. Resources and company goals

b. Competition environment

c. Economic and technological environment

d. Political and legal environment

e. Social and cultural environment

2. Controlled environmental factors within the company are called Marketing Mix (Taylor, 2005: 84).

Sales growth is calculated by the formula:

$$
\text { sales }=\frac{S t-(S t-1)}{S t-1}
$$

Information :

$\mathrm{St}=$ Sales in year $\mathrm{t}$

St -1 = Sales before year t (Kesuma, 2009: 41)

\section{Operating Cash Flow}

\section{Definition of Operating Cash Flow}

According to PSAK No. 2 (IAI, 2007: 3) Cash flows from operating activities are "indicators that determine whether a company's operations can generate sufficient cash flows to repay loans, maintain operating capability, pay dividends, and make new investments without relying external funding sources ". Operating activity is the main revenue generating activity of the company (principal revenue activities). Therefore, the cash flows generally come from transactions that affect the determination of net profit or loss.

According to PSAK No.2, it is explained that cash flows from operating activities represent cash flows derived from the main income generating activities of the company and other activities that are not investment and funding activities.

The cash flows in and out of operations include:

1) Incoming cash flows from the sale of goods and services, dividend income, interest income and other operating receipts.

2) Cash outflow for payments to suppliers of goods and services, payment of corporate debt, tax payments and other operating expenses. 


\section{Concept Framework}

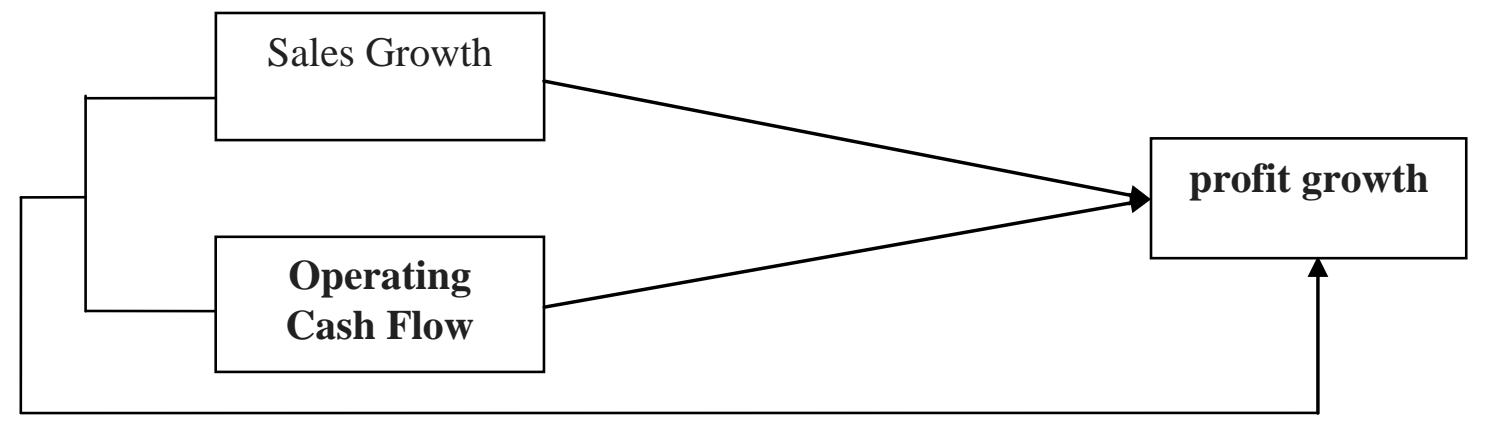

Hypothesis: There is an effect of Sales Growth on Profit Growth. There is an effect of Cash Flow of Operations on Profit Growth. There is a simultaneous influence of Sales Growth and Operating Cash Flow to Profit Growth

\section{Research Methods}

The research approach used in this research is associative approach. An associative approach is an approach done to determine the relationship or influence between two or more variables. In this research, the researcher wants to know the influence of Sales Growth and Operating Cash Flow to Profit Growth. The research approach uses quantitative data types. The data source used is secondary data which is an annual publication report, obtained by accessing www. idx. co.id.

The population of this study is a ceramic company listed on the Indonesian stock exchange that submits its financial statements every year, as many as 5 (five) companies in the period 2010-2015.

\section{Data analysis method}

Data analysis method used to test the hypothesis is multiple linear regression to test and processing data using SPSS.

Multiple linear regression equation in this research is as follows: $\mathrm{Y}=\alpha+\beta 1 \mathrm{P} . \mathrm{P}+\beta 2 \mathrm{AKO}+\mathrm{e}$

Information :

$\mathrm{Y}=$ Profit growth

P.P = Sales Growth

$\mathrm{AKO}=$ Cash Flow Operation $(\mathrm{Ln})$

$\alpha=$ Constants

$\beta=$ regression coefficient

$\mathrm{e}=$ error of term

\section{Classic assumption test}

Before performing hypothesis testing, a classical assumption test is performed in order that the regression model can generate an unbiased estimator. The classical assumption test consists of: a. Normality test

According to Ghozali (2013) normality test aims "to test whether in the regression model, the disruptive or residual variable has a normal distribution". Normality test in this study was conducted by using Kolmogorov-Smirnov test, with a significance level of $5 \%$. The basis of the decision of the normality test is to see the probability of asymp.sig (2-tailed) $>0,05$ then the data is normally distributed and vice versa if asymp.sig (2-tailed) $<0,05$ then the data is not normally distributed.

b. Multicolinearity

Multicollinearity test aims to test whether in the regression model found the existence of correlation (relationship) between independent variables (Ghozali, 2013). A good regression model should not occur correlation between independent variables (no multicollinearity). To identify the presence or absence of multicollinearity in this study, it can be seen from the amount of tolerance and variance inflation factor (VIF). Limit tolerance values with the following conditions:

1. If tolerance values $<0.10$ and VIF $>10$, then there is a correlation between one independent variable with other independent variables or multicolinearity occurs. 
2. If the tolerance value $>0.10$ and VIF $<10$, then there is no correlation between one independent variable with other independent variables or does not occur multicollinearity.

3. Multicollinearity test can also be seen from the correlation value between independent variables. If the value of correlation between independent variables below $95 \%$, it can be concluded that there is no multicollinearity.

c. Heteroscedasticity

According to Ghozali (2013) heteroscedasticity test aims to "test whether in the regression model there is a variance inequality of the residual one observation to another observation. If the variance of the residuals of one observation of another remains, then it is called homoscedasticity and if different it is called heterokedastisitas. A good regression model is Homocedasticity or Heterocedasticity does not occur. The heteroscedasticity test is detected by looking for the presence or absence of a particular pattern on the scatterplot chart

\section{Hypothesis testing}

F test is used to see the effect of independent variables simultaneously on the dependent variable. If the value of fcount $>$ ftable with a significant level less than $5 \%$ can be stated that the independent variables simultaneously have a significant effect on the dependent variable. On the other hand, f count <ftabel with a significant level greater than $5 \%$, it can be concluded that simultaneously independent variables have no significant effect on the dependent variable (Ghozali, 2013).

$\mathrm{T}$ test is used to see the influence of independent variables partially to the dependent variable. Criteria for decision making $t$ test If tcount with a significant level smaller than $5 \%$ then partially independent variables significantly influence the dependent variable. Conversely, with a significant level greater than 5\% then partially independent variables do not significantly affect the dependent variable (Azuar et al, 2014).

\section{Coefficient of Determinant (R2)}

Coefficient of determination (R2) aims to measure the ability of the model in explaining the variation of the dependent variable. The coefficient of determination is between zero and one. A value close to one means the independent variables provide almost all the information needed to predict the dependent variable and vice versa if close to zero (Ghozali, 2013). 3. RESEARCH RESULT AND DISCUSSION 3.1. Research result This study aims to determine the effect of sales growth and operating cash flow to the profit growth of porcelain companies in the BEI. The information used is the annual publication financial report.

\section{Normality Test}

table 1: One-Sample Kolmogorov-Smirnov Test

\begin{tabular}{|ll|r|r|r|}
\hline & & X1 & X2 & \multicolumn{1}{|c|}{ Y } \\
\hline $\mathrm{N}$ & & 35 & 35 & 35 \\
Normal Parameters(a,b) & Mean & 2.7947 & 21.9537 & 3.1967 \\
& Std. Deviation & 1.47291 & 4.72196 & 1.78454 \\
Most Extreme & Absolute & .245 & .191 & .085 \\
Differences & & .245 & .168 & .083 \\
& Positive & -.143 & -.191 & -.085 \\
& Negative & $\mathbf{1 . 3 4 0}$ & $\mathbf{1 . 0 4 7}$ &. $\mathbf{4 6 6}$ \\
Kolmogorov-Smirnov Z & & .055 & .223 & .982 \\
Asymp. Sig. (2-tailed) & & & & \\
a Test distribution is Normal. & & & \\
b Calculated from data. & &
\end{tabular}

Kolmogrov Smirnov test variable was obtained at 1.340 for $\mathrm{x} 1,1.047$ for $\mathrm{x} 2$ and 0.466 for $\mathrm{Y}$ with significance at $0.055 ; 0.223$; and 0.982 . The significance value greater than 0.05 means that the residual data is normally distributed. 
Table 2:

\begin{tabular}{|c|c|c|c|c|c|c|c|}
\hline \multicolumn{4}{|c|}{ Unstandardized Coefficients } & \multirow[b]{2}{*}{$\mathrm{T}$} & \multirow[b]{2}{*}{ Sig. } & \multirow[b]{2}{*}{ tolerance } & \multirow[b]{2}{*}{ VIF } \\
\hline & & $\mathrm{B}$ & Std. Error & & & & \\
\hline \multirow[t]{3}{*}{1} & (Constant) & -1232.023 & 662.419 & -1.860 & .072 & & \\
\hline & $\mathrm{x} 1$ & .025 & .242 & .105 & .917 & .996 & 1.004 \\
\hline & $\mathrm{x} 2$ & 100.072 & 53.886 & 1.857 & .073 & .996 & 1.004 \\
\hline
\end{tabular}

The result of multicollinearity test between independent variables indicated from the tolerance value of each independent variable of 0.996 , greater than 0.1 and VIF value of 0.004 is smaller than 10 that does not happen multicollinearity.

In the heteroscedastic test, spreading dots randomly and scattered either above or below the number 0 on the $\mathrm{Y}$ axis means free of heteroscedasticity.

After performing the classical assumption test followed by data processing using multiple linear regression that produces equations:

$\mathrm{Y}=-1232,023+0,025 \mathrm{PP}+100,072 \mathrm{AKO}+\varepsilon$

\section{Hypothesis testing}

\section{Test F}

table 3

\begin{tabular}{|l|r|rrr|r|}
\hline & & & & & \\
Model & R Square & F & Sig . F & Durbin Watson \\
\hline 1 & .099 & 1.748 & .190 & 2.000 \\
\hline
\end{tabular}

Based on table 3, the F test value of 1.748 (smaller than the F table value) and sig 0.190 (greater than $5 \%$ ).

\section{Test $\mathrm{t}$}

Based on table 2, the value of $\mathrm{t}$ arithmetic for X1 (Sales growth) of 0.917 significant 0.996, as well as X2 of 0.073 with a significant value of 0.996 (greater than 5\%).

Coefficient of Determinant (R2)

The value of the determinant coefficient (R2) in table 3 shows the number 0.099 with significant 0.190 (greater than 5\%).

\section{Discussion}

In this study the equation for multiple linear regression has been fulfilled, with value: $\mathrm{Y}=-1232,023+$ $0,025 \mathrm{PP}+100,072 \mathrm{AKO}+\varepsilon$, it is significant if sales growth increase $100 \%$, then profit growth will increase equal to 0,025 rupiah. And if the cash flow from operating activities increased $100 \%$, then the profit growth will increase by 100,072 rupiah.

\section{Test $\mathbf{F}$}

Figures of 1.748 smaller than F table 3.28 with significant 0.190 (greater than 5\%) indicate that independent variables together do not significantly influence profit growth in ceramic companies listed on the stock exchange.

\section{Test t}

Influence of sales growth on profit growth

The value of titung for X1 (Growth of Sales) of 0.917 with significant 0.996 greater than 0.05 indicates that partially sales growth significantly affects profit growth in ceramics companies listed on the Indonesia Stock Exchange. 
Similarly, the titung value of X2 (Operating Cash Flow) 0.073 with significant 0.996 which is also greater than 0.05 indicates that Operating cash flow significantly affects profit growth in Ceramic companies listed in Indonesia Stock Exchange. This is in accordance with research conducted by Surtati and sulaeman (2011) research results show that cash flow operations affect the growth of corporate profits. The cash flow statements provide information that enables users to evaluate changes in the company's net assets, financial structure (including liquidity and solvency) and the ability to influence the amount and timing of cash flows in order to adapt to changing circumstances and opportunities. The cash flow statement is said to contain information if it is included in the financial statements, so investors react to invest in shares (sale or purchase of shares) in the company.

\section{Coefficient of Determinant (R2)}

The coefficient of determination (R2) aims to measure the ability of the model in explaining the variation of the dependent variable. The determinant coefficient (R2) value of 0.99 with significant 0.190 (greater than 5\%) indicates $9.9 \%$ growth factor can be explained by Sales Growth and Operating cash flow, and the rest of the other $90.1 \%$ are explained by other factors not explained in this study such as: size of company, company age, levarage rate, sales level, changes in earnings in the past.

\section{CONCLUDE AND ADVICE}

\section{Conclusion}

Based on the results of the research it can be concluded that:

a. The variables of sales growth and operating cash flow together do not have a significant effect on profit growth in ceramic companies listed in Indonesian beursa effect.

b. Sales Growth Variables significantly influence Profit Growth at ceramic companies listed in Indonesia stock exchanges.

c. Operating Cash Flow Variable significantly influence Profit Growth at ceramic company listed in Indonesian stock exchange.

\section{Coefficient of Determinant (R2)}

The coefficient of determination (R2) aims to measure the ability of the model in explaining the variation of the dependent variable. The determinant coefficient (R2) value of 0.99 with significant 0.190 (greater than 5\%) indicates 9.9\% growth factor can be explained by Sales Growth and Operating cash flow, and the rest of the other $90.1 \%$ are explained by other factors not explained in this study such as: size of company, company age, levarage rate, sales level, changes in earnings in the past.

\section{CONCLUDE AND ADVICE}

\section{Conclusion}

Based on the results of the research it can be concluded that:

a. The variables of sales growth and operating cash flow together do not have a significant effect on profit growth in ceramic companies listed in Indonesian beursa effect.

b. b. Sales Growth Variables significantly influence Profit Growth at ceramic companies listed in Indonesia stock exchanges.

c. c. Operating Cash Flow Variable significantly influence Profit Growth at ceramic company listed in Indonesian stock exchange.

\section{Suggestion}

Based on the conclusion of the above research results, then the researchers can submit some suggestions as follows:

Based on the above conclusions, the suggestions that can be given in the next research include:

a. Future research is expected to use longer research periods so it is expected to obtain more accurate results and can be generalized.

b. Further research is expected to add independent variables that also influence profit growth.

c. Further research is expected to use more samples with more diverse characteristics from different sectors so that the results are even better. 


\section{REFERENCES}

Akbar, Faisal, 2009. Pemerintahan Daerah dan Sumber-sumber Pendapatan Asli. Daerah, Medan: Penerbit PT. Sofmedia

Ali Kesuma. (2009). Analisis Faktor yang Mempengaruhi Struktur Modal Serta Pengaruhnya Terhadap Harga Saham Perusahaan Real Estate yang Go Publik di Bursa Efek Indonesia. Jurnal Manajemen dan Kewirausahaan, 11(1), 38-45

Amstrong, Gary \& Philip, Kotler. 2002. Dasar-dasar Manajemen Keuangan. Jilid 1, Alih Bahasa Alexander Sindoro dan Benyamin Molan. Jakarta: Penerbit Prenhalindo.

Azuar Juliandi, Irfan dan Saprinal Manurung. 2014. Metodologi Penelitian Bisnis. Medan: UMSU Press.

Bogdan, R.C dan Taylor. 2005. Pengantar Metode Penelitian Kuantitatif Suatu Pendekatan Fenomenologis terhadap Ilmu-Ilmu Sosial. Surabaya:Usaha Nasional

Brealey, Richard A, Stewart C. Myers, dan Alan J. Marcus. 2008. Dasar-dasar Manajemen Keuangan Perusahaan. Jilid 2. Edisi Kelima. Jakarta: Erlangga.

Fabozzi, Frank J. 2000. Manajemen Investasi. Jakarta: Salemba Empat

Ghozali, Imam. 2013. Aplikasi Analisis Multivariate dengan Program SPSS cetakan VII. Semarang : Universitas Diponegoro.

Ikatan Akuntan Indonesia (IAI). 2007. Standar Akuntansi Indonesia. Jakarta: Salemba Empat

Jogiyanto, Hartono, 2005. Analisis \& Desain Sistem Informasi Pendekatan Terstruktur Teori dan Praktek Aplikasi Bisnis. Andi Yogyakarta

Kasmir, 2012. Analisis Laporan Keuangan, Edisi Pertama. Jakarta: PT Raja Grafindo Persada

Ratnawati. 2007. Faktor-Faktor yang Mempengaruhi Pertumbuhan Internal. JAAI Volume 6 No. 2, Desember 2002

Sitanggang. J.P. 2012. Analisis Laporan Keuangan, Bandung: Indeks

Surtati dan Adi Sulaeman, 2011. Pengaruh Arus Kas Operasi Terhadap Pertumbuhan Laba Perusahaan Studi Kasus Pada PT. Multi Manunggal. Jurnal Ilmiah Ranggading Volume 11 No. 2.

www.idx.co.id. Laporan Keuangan tahunan Perusahaan Keramik, diakses pada 12 Desember 2017. 